\title{
UPAYA MENINGKATKAN HASIL BELAJAR EKONOMI MATERI KESEIMBANGAN PASAR MELALUI MODEL KOOPERATIF TIPE THINK PAIR AND SHARE DI SMAN 8 TEBO
}

\author{
INCE TORADINA BUTARBUTAR \\ SMA Negeri 8 Tebo Provinsi Jambi \\ inceetoradinaa2018@gmail.com
}

\begin{abstract}
ABSTRAK
Penelitian ini bertujuan untuk meningkatkan hasil belajar Ekonomi materi keseimbangan pasar melalui model pembelajaran kooperatif tipe think pair and share (TPS) di SMA Negeri 8 Tebo semester ganjil tahun ajaran 2019/2020. Dalam penelitian yang digunakan yaitu jenis Penelitian kualitatif dengan pendekatan penelitian tindakan kelas (PTK), yang memiliki karakteristik yaitu mendeskripsikan semua informasi/data secara alamiah. Teknik pengumpulan data dalam penelitian ini adalah tes dan observasi. Teknik analisis data dalalm penelitian ini menggunakan rumus persentase ketuntasan klasikal dan individual serta rumus $N$-Gain. Berdasarkan hasil penelitian dapat disimpulkan bahwa siswa lebih aktif terhadap pembelajaran dengan menggunakan model pembelajaran tipe think pair and share (TPS) hal ini dapat terlihat dari hasil pengamatan aktivitas siswa yang pada siklus 1 dengan memperoleh skor rata -rata 3,18 dengan kriteria baik dan pada siklus II memiliki skor rata-rata 3,75 dengan kriteria baik, dengan demikian upaya guru agar siswa lebih aktif dapat dikatakan berhasil. Berdasarkan hasil penelitian disimpulkan bahwa hasil belajar siswa setelah menggunakan model pembelajaran tipe think pair and share (TPS) juga mengalami peningkatan yang lebih baik dan aktif dalam kemampuan memahami materi. Hasil tes pada siklus I secara klasikal sebesar 69\% terdapat 16 siswa yang memperoleh nilai $\geq 75$ dari 23 siswa dan terjadi peningkatan kembali pada siklus II sebesar $100 \%$.
\end{abstract}

Kata Kunci: hasil belajar, keseimbangan pasar, model pembelajaran tipe think pair and share.

\begin{abstract}
This study aims to improve learning outcomes of market balance material Economics through a think pair and share (TPS) cooperative learning model at SMA Negeri 8 Tebo in the odd semester of the 2019/2020 school year. The research used is a type of qualitative research with a classroom action research approach (CAR), which has the characteristic that it describes all information/data naturally. Data collection techniques in this study were tests and observations. The data analysis technique in this study uses the classical and individual completeness percentage formula and the N-Gain formula. Based on the results of the study, it can be concluded that students are more active in learning by using the think pair and share (TPS) type of learning model, this can be seen from the results of observing student activities in cycle 1 by obtaining an average score of 3.18 with good criteria and Cycle II has an average score of 3.75 with good criteria, thus the teacher's efforts to make students more active can be said to be successful. Based on the results of the study, it was concluded that student learning outcomes after using the think pair and share (TPS) type of learning model also experienced a better and more active increase in the ability to understand the material. The test results in the first cycle classically were $69 \%$, there were 16 students who scored 75 out of 23 students and there was an increase again in the second cycle of $100 \%$.
\end{abstract}

Keywords: learning outcomes, market balance, think pair and share learning model.

\section{PENDAHULUAN}

Salah satu usaha guru dalam meningkatkan hasil belajar siswa adalah dengan membuat pembelajaran tidak tertinggal sehingga perlu adanya penyesuaian-penyesuaian terutama yang berkaiatan dengan faktor-faktor pengajaran disekolah (Arnidha, 2016). Salah satu faktor tersebut adalah model pembelajaran yang perlu dipelajari dan dikuasai oleh guru, sehingga 
mereka dapat menyampaikan materi pelajaran kepada siswa secara baik berdaya guna dan berhasil. Untuk itu model pembelajaran dalam proses belajar mengajar adalah suatu kenyataan yang tidak bisa dipungkiri keberadaanya. Keberadaan model pembelajaran sangat membantu tugas guru dalam meyampaikan pesan-pesan dari bahan pelajaran yang akan disampaikan oleh guru kepada siswa. Guru sadar bahwa tanpa menggunakan model pembelajaran, maka proses pembelajaran dan bahan pelajaran sukar untuk dipahami oleh setiap siswa terutama bahan pelajaran yang sangat kompleks dan rumit (Ni'mah, dkk, 2014).

Berbagai inovasi dalam pendidikan ekonomi telah dilakukan dalam kurun waktu terakhir ini. Hal ini merupakan upaya untuk membelajarkan siswa sehingga mereka dapat belajar secara optimal. Salah satu model pembelajaran yang bisa digunakan untuk meningkatkan hasil belajar, membuat pembelajaran menjadi menyenangkan, dan mengembangkan sikap bekerja sama adalah model pembelajaran kooperatif (Suryani, 2018). Dalam pembelajaran kooperatif siswa belajar bersama sebagai suatu tim dalam menyelesaikan tugas-tugas kelompok untuk mencapai tujuan bersama, sehingga setiap anggota kelompok memiliki tanggung jawab yang sama untuk keberhasilan kelompoknya. Ada beberapa variasi dalam model pembelajaran kooperatif, yakni STAD, Jigsaw, Group Investigation (GI), Teams Games Tournaments (TGT), Think Pare Share (TPS), dan Numbered Head Together (NHT) (Surayya, dkk, 2014).

Model pembelajaran kooperatif tipe think pair share merupakan model pembelajaran kooperatif yang efektif untuk membuat variasi suasana pola diskusi. Prosedur yang digunakan dalam model think pair share dapat memberi siswa lebih banyak waktu berpikir, merespon dan saling membantu (Febrianto, dkk, 2016).

Menurut Sudarsana (2018) latihan bekerja sama bisa dilakukan dengan pengelompokan sederhana, yakni dengan dua siswa dalam satu kelompok yang ditugaskan untuk menyelesaikan tugas kognitif. Teknik ini merupakan cara paling sederhana dalam organisasi sosial. Dengan demikian model pembelajaran think-pair-share sangat ideal untuk guru dan siswa yang baru belajar kolaboratif. Teknik pembelajaran think pair share memberi siswa kesempatan untuk bekerja sendiri serta bekerja sama dengan orang lain. Keunggulan lain dari teknik ini adalah optimalisasi partisipasi siswa. Teknik ini memberi kesempatan lebih banyak kepada setiap siswa untuk dikenali dan menunjukkan partisipasi mereka kepada orang lain (Lombu, 2019).

Model pembelajaran think pair share terdiri dari tiga tahap, yaitu tahap thinking (berpikir), pairing (berpasangan), dan sharing (berbagi). Pada tahap think siswa harus berpikir sendiri tentang jawaban atas permasalahan yang diberikan oleh guru. Berpikir merupakan proses kognitif, yaitu suatu aktivitas mental untuk memperoleh pengetahuan. Ketika harus berpikir, maka akan ada dialog dengan diri sendiri. Pada tahap pair, siswa akan berpasangan untuk mendiskusikan hasil berpikir sebelumnya (Anggara, 2016).

Dalam berdiskusi diperlukan beberapa keterampilan berpikir, antara lain: mengenal masalah; menemukan cara-cara yang dapat dipakai untuk menangani masalah-masalah tersebut; mengumpulkan dan menyusun informasi yang diperlukan; memahami dan menggunakan bahasa yang tepat dan jelas; menganalisis data; dan menarik kesimpulan. Keterampilan-keterampilan berpikir ini merupakan landasan untuk berpikir kritis. Sedangkan pada tahap share, siswa akan berbagi dengan seluruh kelas. Pada tahap ini diperlukan diperlukan kemampuan untuk mengatakan sesuatu dengan penuh percaya diri. Dengan demikian setiap tahap yang terdapat dalam model pembelajaran think pair share merupakan keterampilan berpikir, landasan berpikir kritis, dan definisi keterampilan berpikir kritis (Wakijo, dkk, 2019).

Proses belajar mengajar pada hakikatnya adalah proses komunikasi, yaitu proses penyampaian pesan dari sumber pesan melalui saluran atau media tertentu ke penerima pesan. Adakalanya penerima pesan (siswa) benar dalam menafsirkan pesan yang disampaikan oleh guru, tetapi adakalanya mereka salah dalam menafsirkan. Ada beberapa faktor yang menjadi penghambat atau penghalang proses komunikasi, diantaranya hambatan psikologis, hambatan kultural, dan hambatan lingkungan. 
Dalam pembelajaran ekonomi di kelas X IPS 1 SMA Negeri 8 Tebo, guru ekonomi kelas X IPS 1 SMA Negeri 8 Tebo sering menghadapi masalah dimana hasil belajar siswa yang belum sesuai dengan yang diharapkan (belum tuntas), dengan rata-rata 57\% (13 siswa) yang belum mencapai nilai Kriteria Ketuntasan Minimal (KKM) 13 siswa mendapatkan nilai antara 50 sampai 74 dari 23 siswa, sedangkan yang 43\% (10 siswa) dapat mencapai nilai Kriteria Ketuntasan Minimal (KKM), sedangkan menurut guru ekonomi kelas X IPS 1 SMA Negeri 8 Tebo nilai Kriteria Ketuntasan Minimal (KKM) untuk pelajaran ekonomi adalah 75. Berdasarkan pengamatan terhadap siswa kelas X IPS 1 SMA Negeri 8 Tebo, siswa kurang tertarik pada mata pelajaran ekonomi karena materi ekonomi kadang sulit untuk dipahami oleh siswa. Oleh sebab itu, untuk meningkatkan hasil belajar ekonomi dengan pokok bahasan keseimbangan pasar diperlukan model pembelajaran yang mampu membuat siswa lebih memahami pelajaran, salah satu model pembelajaran yang lebih mudah untuk memahami materi ekonomi dengan pokok bahasan adalah dengan menggunakan model pembelajaran kooperatif tipe think pair and share (TPS).

Siswa kelas X IPS 1 SMA Negeri 8 Tebo juga kurang paham dengan isi materi ekonomi apa lagi dihadapkan dengan materi-materi yang baru dimana siswa belum pernah mengalaminya ini juga salah satu faktor sehingga hasil belajar siswa rendah. Untuk itu dalam penelitian ini digunakan model pembelajaran kooperatif tipe think pair and share (TPS) dengan penjelasan dari guru guna meningkatkan hasil belajar ekonomi

Menurut Sudjana dalam Nurhasanah, dkk (2016) hasil belajar merupakan kemampuankemampuan yang dimiliki seorang siswa setelah ia menerima perilaku atau menerima pengalaman belajarnya dari pengajar (guru). Sedangkan menurut Omar Hamalik dalam Nasution (2018) hasil belajar adalah bila seseorang telah belajar akan terjadi perubahan tingkah laku pada orang tersebut, misalnya dari tidak tahu menjadi tahu, dari tidak mengerti menjadi mengerti. Hasil belajar juga merupakan sesuatu yang dicapai atau diperoleh siswa berkat adanya usaha atau pikiran yang mana hal tersebut dinyatakan dalam bentuk penguasaan, pengetahuan dan kecakapan dasar yang terdapat dalam berbagai aspek kehidupan sehingga nampak pada diri indivdu penggunaan penilaian terhadap sikap, pengetahuan dan kecakapan dasar yang terdapat dalam berbagai aspek kehidupan sehingga nampak pada diri individu perubahan tingkah laku secara kuantitatif (Nurrita, 2018). Ekonomi adalah ilmu tentang prilaku dan tindakan manusia untuk memnuhi kebutuhan hidupnya yang banyak, bervariasi, dan berkembang dengan sumber daya yang ada melalui pilihan-pilihan kegiatan produksi, konsumsi, dan atau distribusi (Widiasih, dkk, 2018).

Dari penjelasan di atas dapat disimpulkan bahwa hasil belajar ekonomi adalah penilaian yang dicapai seorang siswa untuk mengetahui tercapai atau tidaknya bahan pelajaran atau materi ekonomi yang diajarkan sudah dapat dimengerti siswa atau masih belum dapat dimengerti siswa.

\section{METODE PENELITIAN}

Penelitian ini dilaksanakan di SMA Negeri 8 Tebo, Provinsi Jambi, Dengan subjek penelitian siswa kelas X IPS ruang 1 (X IPS 1). Dalam penelitian yang digunakan yaitu jenis Penelitian kualitatif dengan pendekatan PTK, yang memiliki karakteristik yaitu mendeskripsikan semua informasi/data secara alamiah/apa adanya, dan Peneliti sebagai instrumen utama.

Teknik pengumpulan data yang digunakan dalam penelitian ini adalah tes dan observasi, penelitian ini akan menggunakan data kualitatif dan data kuantitatif. Data kuantitatif berupa tes hasil belajar yaitu untuk mengumpulkan data kuantitatif hasil belajar siswa pada pembelajaran ekonomi. Sedangkan data kualitatif diperoleh melalui Observasi yaitu untuk mengumpulkan data aktivitas siswa dan pendidik.

Instrumen dalam penelitian ini meliputi instrumen tes dan non tes, instrumen tes dalam penelitian ini dilakukan dengan teknik tes tertulis dalam bentuk essay, diberikan kepada siswa pada awal penelitian dan pada akhir tindakan sebagai bukti yang menunjukkan ada atau 
tidaknya peningkatan hasil belajar siswa dalam pembelajaran ekonomi melalui penggunaan model pembelajaran kooperatif tipe think pair and share (TPS). Sedangkan instrumen non tes yang digunakan adalah observasi, observasi yang digunakan adalah observasi secara langsung instrumen observasi digunakan untuk melihat aktivitas pendidik dan keaktifan siswa dalam proses belajar ketika pendidik menggunakan model pembelajaran kooperatif tipe think pair and share (TPS). Validitas instrument ditentukan melalui pendapat para ahli tentang isi materi tes, para ahli yang memutuskan valid atau tidaknya isi tes yaitu dengan meminta bantuan dari dua orang ratter sebagai validator.

Data yang diperoleh melalui instrumen yang telah dikumpulkan sebelumnya diolah menjadi dua jenis data yaitu kuantitatif dan kualitatif. Data kuantitatif berasal dari pos test yang dilakukan diakhir pertemuan. Hal ini dilakukan untuk mengetahui peningkatan hasil belajar dan keaktifan bertanya siswa dalam pembelajaran.

Perhitungan data kuantitatif dalam penelitian ini meliputi: 1) menghitung nilai rata-rata kelas, 2) menghitung persentase ketuntasan secara klasikal, dan 3) menghitung peningkatan hasil belajar. Data kualitatif diperoleh dari hasil observasi yang dimaksud untuk mengetahui kelebihan dan kekurangan dari pembelajaran yang dilakukan, data kualitatif diperoleh dari aktivitas siswa dan guru dalam proses pembelajaran dengan menganalisis keaktifan bertanya siswa dan keefektifan pembelajaran yang dikelola guru dengan menggunakan model pembelajaran kooperatif tipe think pair and share.

Adapun indikator hasil belajar pada pre test (tes Awal) dan Pos test (tes Akhir) adalah: 1) terjadi perubahan aktifitas belajar siswa kelas X IPS 1 SMA Negeri 8 Tebo menjadi lebih aktif setelah menggunakan model pembelajaran kooperatif tipe think pair and share, 2) peningkatan nilai atau hasil belajar siswa, berdasarkan hasil pre test dan pos test serta dilihat dari ketuntasan belajar yang diharapkan mencapai nilai KKM yaitu 75 pada bidang studi ekonomi kelas X IPS 1 SMA Negeri 8 Tebo.

\section{HASIL DAN PEMBAHASAN}

\section{Siklus I}

Hasil penelitian siklus I yang terdiri dari (1) Kegiatan guru dan aktivitas siswa, (2) Hasil belajar dan (3) Refleksi Siklus I. Hasil penelitian tersebut disajikan sebagai berikut:

Aktivitas Guru, aspek pengamatan difokuskan pada aktivitas guru yang terdiri dari 20 bagian hasil rata-rata penilaian ke dua observer atau kedelapan bagian tersebut adalah: (1) Memeriksa kesiapan siswa belajar (3), (2) Kesiapan perlengkapan pembelajaran (3,5), (3) Menunjukan kegairahan mengajar (3), (4) Merumuskan tujuan dan memotivasi (3,25), (5) Penjelasan materi pembelajaran (3,5), (6) Penggunaan metode (3,5), (7) Menguasai kelas 2,5, (8) Penggunaan media, (a) menggunakan model pembelajaran saat kegiatan belajar mengajar $(3,5)$, (b) model pembelajaran yang digunakan meningkatkan pemahaman siswa $(3,5),(9)$ Melaksanakan pembelajaran sesuai dengan alokasi waktu (3), (10) Menumbuhkan partisipasi aktif siswa dalam pembelajaran $(3,5)$, (11) Suara dan bahasa yang digunakan $(2,5),(12)$ Kemampuan melibatkan siswa dalam KBM $(3,5)$, (13) Menunjukan sikap ramah, hangat, terbuka, penuh pengertian, dan sabar kepada siswa $(3,5),(14)$ Tanya jawab antar siswa dan guru (3,5), (15) Melaksanakan penilaian, (a) Menilai hasil evaluasi siswa (3,5), (b) Memberi pujian terhadap hasil belajar siswa $(3,5),(16)$ Kegiatan belajar mengajar cenderung berpusat pada siswa (3), (17) Menyimpulkan materi pembelajaran (3), (18) Memberikan evaluasi (mengerjakan soal) (4), (19) Mendorong siswa lebih giat belajar (3), (20) Menutup pembelajaran $(3,5)$. Sesuai dengan hasil di atas dapat diperoleh hasil rata-rata dari keseluruhan bagian aspek tersebut memperoleh nilai rata-rata 3,32 dengan demikian aspek aktivitas guru dapat dikategorikan baik.

Aktivitas Siswa, aspek aktivitas siswa yang terdiri dari 8 bagian menghasilkan rata-rata penilaian pengamatan yaitu: (1) Memperhatikan penjelasan guru (3), (2) Ketertarikan siswa untuk belajar bila menggunakan model pembelajaran (3,5), (3) Menulis sesuai dengan kegiatan pembelajaran (3), (4) Mengajukan pertanyaan kepada guru tentang hal yang belum jelas $(3,5)$, 
(5) Keaktifan siswa selama proses belajar $(2,5)$, (6) Mengerjakan lembar kegiatan $(3,5),(7)$ Perilaku yang sesuai dengan kegiatan pembelajaran (3), (8) Interaksi atar sesama siswa $(3,5)$. Berdasarkan penilaian rata-rata atas masing-masing bagian aspek aktivitas siswa diatas maka diperoleh nilai rata-rata keseluruhan bagian aspek tersebut adalah 3,18 dengan demikian aspek aktivitas siswa dapat dikategorikan baik.

Hasil belajar Siklus I, dari hasil belajar pada siklus I cukup mencapai indikator penelitian yaitu 75,43 hasil ini merupakan terbilang cukup mencapai Kriteria Ketuntasan Mengajar (KKM) untuk pelajaran Ekonomi yaitu 75. Namun belum mencapai ketuntasan belajar secara klasikal. Jadi, hasil belajar Ekonomi pada materi keseimbanga pasar siklus I ini tercapai secara individual belum secara klasikal.

Hasil Refleksi Siklus I, hasil refleksi pada siklus I menghasilkan saran dari pengamat, yaitu mengubah posisi tempat duduk siswa menjadi 2 orang siswa dirapatkan sehingga siswa lebih aktif dan interaktif, sehingga dengan model kooperatif tipe think pair share (TPS) dapat meningkatkan hasil belajar siswa pada mata pelajaran ekonomi. Hasil refleksi pada siklus I tersebut dijadikan sebagai bahan pertimbangan bagi peneliti untuk melakukan langkah-langkah perbaikan di siklus II sehingga kegiatan pembelajaran yang berfokus pada usaha untuk meningkatkan hasil belajar siswa kelas X IPS 1 SMA Negeri 8 Tebo.

\section{Siklus II}

Hasil penelitian siklus II dilakukan untuk meningkatkan hasil belajar ekonomi dengan pokok bahasan keseimbangan pasar. Dimana pada hasil siklus I tersebut masih kurang maksimal, sehingga tingkat pemahaman siswa perlu ditingkatkan lagi dengan tujuan mencapai nilai yang maksimal. Hasil penelitian tindakan kelas pada siklus II juga terdiri atas beberapa aspek. Aspek tersebut adalah (1) aktivitas guru dan aktivitas siswa, (2) Hasil belajar dan, (3) Refleks hasil penelitian siklus II adalah sebagai berikut:

Aktivitas Guru, aspek pengamatan difokuskan pada aktivitas guru terdiri dari 20 aspek. Hasil rata-rata diperoleh dari dua observer. Dimana kedua puluh aspek tersebut adalah: (1) Memeriksa kesiapan siswa belajar $(3,5),(2)$ Kesiapan perlengkapan pembelajaran $(3,5),(3)$ Menunjukan kegairahan mengajar (4), (4) Merumuskan tujuan dan memotivasi (3,75), (5) Penjelasan materi pembelajaran (4), (6) Penggunaan metode (4), (7) Menguasai kelas (3,5), (8) Penggunaan media, (4) menggunakan model pembelajaran saat kegiatan belajar mengajar (4), (9) Melaksanakan pembelajaran sesuai dengan alokasi waktu (4), (10) Menumbuhkan partisipasi aktif siswa dalam pembelajaran (4), (11) Suara dan bahasa yang digunakan (4), (12) Kemampuan melibatkan siswa dalam KBM (4), (13) Menunjukan sikap ramah, hangat, terbuka, penuh pengertian, dan sabar kepada siswa (4), (14) Tanya jawab antar siswa dan guru $(3,5)$, (15) Melaksanakan penilaian, (a) Menilai hasil evaluasi siswa (4), (b) Memberi pujian terhadap hasil belajar siswa (4), (16) Kegiatan belajar mengajar cenderung berpusat pada siswa (4), (17) Menyimpulkan materi pembelajaran (4), (18) Memberikan evaluasi (mengerjakan soal) (4), (19) Mendorong siswa lebih giat belajar (4), (20) Menutup pembelajaran (4). Sesuai dengan hasil di atas dapat diperoleh hasil rata-rata dari keseluruhan bagian aspek tersebut memperoleh skor rata-rata 3,9 dengan demikian aspek aktivitas guru dapat dikategorikan baik.

Aktivitas Siswa, aspek aktivitas siswa yang terdiri dari 8 bagian menghasilkan rata-rata penilaian pengamatan yaitu: (1) Memperhatikan penjelasan guru (4), (2) Ketertarikan siswa untuk belajar menggunakan model pembelajaran (4), (3) Menulis sesuai dengan kegiatan pembelajaran (3), (4) Mengajukan pertanyaan kepada guru tentang hal yang belum jelas (4), (5) Keaktifan siswa selama proses belajar (3), (6) Mengerjakan lembar kegiatan (4), (7) Perilaku yang sesuai dengan kegiatan pembelajaran (4), (8) Interaksi atar sesama siswa (4). Berdasarkan penilaian rata-rata dibagian aspek aktivitas siswa di atas maka diperoleh nilai rata-rata keseluruhan bagian aspek tersebut adalah 3,75 dengan demikian aspek aktivitas siswa dapat dikategorikan baik dan dapat dikatakan berhasil.

Hasil belajar Siklus II, dari hasil belajar pada siklus II sudah mencapai indikator penelitian yaitu skor nilai rata-rata siswa sebesar 85,21 hasil ini merupakan terbilang mencapai 
Kriteria Ketuntasan Mengajar (KKM) untuk pelajaran Ekonomi yaitu 75. Dan sudah mencapai ketuntasan belajar secara klasikal yaitu $100 \%$ atau seluruh siswa kelas X IPS 1 SMA Negeri 8 Tebo mencapai nilai KKM. Jadi, hasil belajar Ekonomi pada materi keseimbangan pasar siklus II ini tercapai secara individual maupun secara klasikal sehingga penelitian ini tidak dilanjutkan ke siklus berikutnya.

Hasil Refleksi pada Siklus II, hasil refleksi pada siklus II menghasilkan saran dari pengamat yaitu agar lebih meningkatkan penggunaan model pembelajaran kooperatif tipe think pair share (TPS) karena disamping dapat meningkatkan hasil belajar juga dapat meningkatkan pemahaman dan ketertarikan siswa untuk belajar khususnya pelajaran ekonomi. Melalui penggunaan model pembelajaran kooperatif tipe think pair share (TPS) diharapkan dapat mempermudah guru untuk mencapai tujuan pembelajaran. Selain itu, penggunaan model pembelajaran kooperatif tipe think pair share (TPS) juga diharapkan dapat menambah keaktifan siswa untuk bertanya selama proses pembelajaran yang secara tidak langsung juga akan meningkatkan hasil belajar siswa hal ini terlihat dari hasil belajar siswa pada pada setiap siklus. Sehingga diharapkan penggunaan model pembelajaran kooperatif tipe think pair share (TPS) ini juga dapat digunakan pada mata pelajaran dan materi lainnya.

\section{KESIMPULAN}

Berdasarkan data hasil penelitian dan pembahasan dalam penelitian tindakan kelas (PTK) yang didapat peneliti selama penelitian dilakukan di SMA Negeri 8 Tebo kelas X IPS 1 adalah sebagai berikut: 1) berdasarkan pengamatan yang dilakukan oleh dua pengamat hasil aktivitas siswa selama pembelajaran ekonomi dengan menggunakan model pembelajaran kooperatif tipe think pair share (TPS) pada siklus I dan II mengalami perubahan. Pada siklus I memperoleh skor rata-rata 3,18 dengan kriteria baik dan pada siklus II menjadi 3,75 dengan kriteria baik pula dengan demikian upaya guru agar siswa lebih aktif dapat dikatakan berhasil, itu berarti ada perubahan aktivitas siswa menjadi lebih aktif. Berdasarkan hasil tersebut dapat disimpulkan bahwa siswa lebih aktif dalam pembelajaran ekonomi dengan materi keseimbangan pasar terhadap kegiatan pembelajaran, dan 2) hasil belajar siswa kelas X IPS 1 SMA Negeri 8 Tebo mengalami peningkatan dari data awal persentasenya didapat $22 \%$ dengan kriteria kurang dominan dengan persentase $100 \%$ dari 23 orang siswa hanya 5 orang siswa yang mendapatkan skor $\geq 75$, pada siklus I terjadi peningkatan menjadi $69 \%$ dengan kriteria cukup dominan dari 23 orang siswa yang memperoleh skor $\geq 75$ adalah 16 orang siswa, dan pada siklus II mengalami peningkatan dengan rata-rata ketuntasan $85,21 \%$ artinya dari 23 orang siswa kelas $X$ IPS 1 SMA Negeri 8 Tebo seluruhnya mendapat skor $\geq 75$ dengan persentase sebesar $100 \%$ dengan kriteria sangat tercapai.

\section{DAFTAR PUSTAKA}

Anggara, D. S. (2016). Peningkatan Kualitas Pembelajaran Matematika Ekonomi Melalui Model Think Pair Share Dengan Media Powerpoint Pada Mahasiswa Kelas 03pie papendidikan ekonomi Universitas pamulang. pekobis Jurnal Pendidikan, Ekonomi dan Bisnis, 2(2), 12-20.

Arnidha, Y. (2016). Peningkatan kemampuan representasi matematis melalui model pembelajaran kooperatif Think Pair Share. JURNAL e-DuMath, 2(1).

Febrianto, E., Joyoatmojo, S., \& Nugroho, J. A. (2016). Upaya Peningkatan Keaktifan dan Hasil Belajar Melalui Model Pembelajaran Think Pair Share (TPS) Berbantuan Media Power Point pada Mata Pelajaran Pengantar Ekonomi dan Bisnis Siswa SMK Negeri I Banyudono Tahun Ajaran 2015/2016. Jurnal Pendidikan Bisnis dan Ekonomi, 2(1).

Lombu, T. C. (2019). Penerapan model pembelajaran think pair share untuk meningkatkan pemahaman konsep ekonomi siswa kelas xi (Doctoral dissertation, Universitas Pelita Harapan).

Nasution, M. K. (2018). Penggunaan metode pembelajaran dalam peningkatan hasil belajar siswa. Studia Didaktika, 11(01), 9-16. 
Ni'mah, A., \& Dwijananti, P. (2014). Penerapan model pembelajaran think pair share (TPS) dengan metode eksperimen untuk meningkatkan hasil belajar dan aktivitas belajar siswa kelas VIII MTs. Nahdlatul Muslimin Kudus. UPEJ Unnes Physics Education Journal, 3(2).

Nurhasanah, S., \& Sobandi, A. (2016). Minat belajar sebagai determinan hasil belajar siswa. Jurnal Pendidikan Manajemen Perkantoran (JPManper), 1(1), 128-135.

Nurrita, T. (2018). Pengembangan media pembelajaran untuk meningkatkan hasil belajar siswa. MISYKAT: Jurnal Ilmu-ilmu Al-Quran, Hadist, Syari'ah dan Tarbiyah, 3(1), 171-210.

Sudarsana, I. K. (2018). Pengaruh model pembelajaran kooperatif terhadap peningkatan mutu hasil belajar siswa. Jurnal Penjaminan Mutu, 4(1), 20-31.

Surayya, L., Subagia, I. W., \& Tika, I. N. (2014). Pengaruh model pembelajaran think pair share terhadap hasil belajar IPA ditinjau dari keterampilan berpikir kritis siswa. Jurnal Pendidikan dan Pembelajaran IPA Indonesia, 4(1).

Suryani, E. (2018). Meningkatkan Hasil Belajar Ekonomi Melalui Pembelajaran Kooperatif Metode Think Pair Share pada Siswa Kelas XI SMA Negeri 3 Mataram. Jurnal Kependidikan: Jurnal Hasil Penelitian dan Kajian Kepustakaan di Bidang Pendidikan, Pengajaran dan Pembelajaran, 4(2), 141-150.

Wakijo, W., \& Puri, L. M. (2019). PENGARUH MODEL PEMBELAJARAN KOOPERATIF THINK PAIR SHARE TERHADAP HASIL BELAJAR EKONOMI SISWA. PROMOSI: Jurnal Program Studi Pendidikan Ekonomi, 7(2).

Widiasih, R., Widodo, J., \& Kartini, T. (2018). Pengaruh penggunaan media bervariasi dan motivasi belajar terhadap hasil belajar mata pelajaran ekonomi siswa kelas XI IPS SMA Negeri 2 Jember Tahun Pelajaran 2016/2017. JURNAL PENDIDIKAN EKONOMI: Jurnal Ilmiah Ilmu Pendidikan, Ilmu Ekonomi Dan Ilmu Sosial, 11(2), 103-107. 